\title{
PEMODELAN GEOGRAPHICALLY WEIGHTED GENERALIZED POISSON REGRESSION (GWGPR) PADA KASUS KEMATIAN IBU NIFAS DI JAWA TENGAH
}

\author{
Wahyu Sabtika ${ }^{1}$, Alan Prahutama ${ }^{2}$, Hasbi Yasin ${ }^{3}$ \\ 1,2,3 Departemen Statistika, Fakultas Sains dan Matematika, Universitas Diponegoro \\ email: wahyusabtika.ws@ gmail.com
}

\begin{abstract}
Maternal mortality is one indicator to describing prosperity in a country and indicator of women's health. Most of the maternal mortality caused by postpartum maternal mortality. The number of postpastum maternal mortality is events that the probability of the incident is small, where the incident depending on a certain time or in a certain regions with the results of the observation are variable diskrit and betw een variable independent each other that follows the Poisson distribution, so that the proper statistical method is Poisson regression. However, in Poisson regression model analys is sometimes as sumptions can occur violations, where the value of variance is greater than the mean value called overdispersion. Generalized Poiss on Regression (GPR) is one model that can be used to handle overdispersion problems. This modeling produces global parameters for all locations (regions), so to overcome this we need a method of statistical modeling with due regard to s patial factors. The analytical method used to determine thefactors that influence the number of postpartum maternal mortality in Central Java that have overdispersion and there are spatial factors, is Geographically Weighted Generalized Poisson Regression (GWGPR) using the Maximum Likelihood Estimation method and Adaptive Bisquare weighting. Poisson regression and GPR modeling produces a variable percentage of pregnant women doing K1 which has a significant effect on the number of postpartummaternal mortality, while for GWGPR modeling is divided into fourcluster in all regency/city in Central Java based on the same significant variable. Fromthe comparis on of AIC values, it was found that the GWGPR model is better for analyzing postpartum maternal mortality in Central Java because it has the smallest AIC value.
\end{abstract}

Keywords: The Number of Postpartum Maternal Mortality, Overdispersion, Generalized Poisson Regression, Spatial, Geograpically Weighted Generalized Poisson Regression, AIC

\section{PENDAHULUAN}

Angka Kematian Ibu (AKI) merupakan salah satu indikator yang menentukan kesejahteraan masyarakat di suatu negara, khususnya berkaitan dengan masalah kesehatan ibu. Kasus kematian ibu banyak terjadi di negara-negara berkembang seperti Indonesia. Oleh karena itu, hal ini menjadi salah satu masalah yang harus diperhatikan oleh pemerintah Indonesia terutama mengenai kesehatan ibu.

Berdasarkan data Kementerian Kesehatan Republik Indonesia tahun 2015 AKI di Indonesia sebesar 305 per 100.000 kelahiran hidup (Kemenkes RI, 2017). Hal ini menjadi perhatian pemerintah sehingga Angka Kematian Ibu menjadi salah satu target dalam Sustainable Development Goals (SDG's) 2015 hingga 2030 dan Rencana Pembangunan Jangka Menengah Nasional (RPJMN) pada tahun 2019 (Bappenas, 2014).

Kematian ibu mencerminkan risiko yang dihadapi ibu selama masa kehamilan sampai dengan pasca persalinan yang dipengaruhi oleh status gizi ibu, keadaan sosial ekonomi, keadaan kesehatan menjelang kehamilan, kejadian berbagai komplikasi pada kehamilan dan kelahiran, tersedianya dan penggunaan fasilitas pelayanan kesehatan ternasuk pelayanan prenatal dan obstetri. Sebagian besar kematian ibu disebabkan oleh kematian ibu nifas. Data dari Dinas Kesehatan Provinsi Jawa Tengah menunjukkan jumlah kematian ibu di Provinsi Jawa Tengah pada tahun 2017 sebanyak 475 kasus, dengan kasus kematian ibu hamil 
sebanyak 125, kematian ibu bersalin sebanyak 65 dan kematian ibu nifas sebanyak 285 (Dinkes Jateng, 2018).

Data jumlah kematian ibu nifas di Jawa tengah merupakan data count yang mengikuti distribusi Poisson sehingga metode statistik yang tepat digunakan untuk menganalisis yaitu regresi Poisson. Data jumlah kematian ibu nifas di Jawa Tengah memiliki nilai varians yang lebih besar dari nilai mean (overdispersi) sehingga perlu dilakukan analisis lain untuk mengatasi masalah tersebut yaitu Generalized Poisson Regression (GPR) (Wang dan Famoye, 1997). Pemodelan ini menghasilkan parameter yang bersifat global untuk seluruh lokasi (daerah). Karakteristik setiap kabupaten/kota bervariasi sehingga diperlukakan suatu pemodelan statistik dengan memperhitungkan faktor lokasi/spasial.

Berdasarkan uraian tersebut, pada penelitian ini dilakukan pemodelan faktor-faktor yang mempengaruhi jumlah kematian ibu nifas di Jawa Tengah menggunakan metode Geographically weighted Generalized Poisson Regression (GWGPR).

\section{TINJAUAN PUSTAKA}

\subsection{Kematian Ibu Nifas}

Kematian ibu nifas adalah kematian ibu yang terjadi selama masa nifas yaitu masa pulih kembali mulai dari persalinan selesai hingga alat-alat kandungan kembali seperti masa prahamil dengan lama masa nifas yaitu 6-8 minggu (Bahiyatun, 2008).

\subsection{Deteksi Multikolinie ritas}

Suatu model regresi dikatakan terdapat multikolinieritas apabila terjadi hubungan linier yang sempurna (perfect) diantara beberapa atau semua variabel bebas dari suatu model regresi. Kasus multikolinieritas dapat diketahui dengan melihat nilai VIF yang bernilai lebih besar dari 10, dengan nilai VIF yang dinyatakan sebagai berikut

$V I F=\frac{1}{1-R_{j}^{2}}$

dengan $\mathrm{R}_{\mathrm{j}}{ }^{2}$ adalah koefisien determinasi antara variabel independen satu dengan variabel independen lainnya.

\subsection{Dis tribusi Poiss on}

Distribusi Poisson adalah suatu distribusi untuk peristiwa yang probabilitas kejadiannya kecil, dimana kejadiannya tergantung pada interval waktu tertentu atau di suatu daerah tertentu dengan hasil pengamatan berupa variabel diskrit. Variabel Y dapat dikatakan berdistribusi Poisson dengan parameter $\mu$ memiliki fungsi probabilitas yang dinyatakan sebagai berikut (Myers, 1990).

$$
f(y, \mu)= \begin{cases}e^{-\mu} \frac{\mu^{y}}{y !}, x=0,1,2, \ldots \\ 0, & x \text { yang lain }\end{cases}
$$

dengan $\mu$ adalah rata-rata variabel respon Y yang berdistribusi Poisson

\subsection{Uji Kecocokan Dis tribusi}

Salah satu metode uji kecocokan distribusi yang sering digunakan adalah uji Kolmogorov-Smirnov. Prinsip dari Uji Kolmogorov-Smirnov adalah menghitung selisih absolut antara fungsi ditribusi frekuensi kumulatif sampel [S(x)] dan fungsi distribusi frekuensi teoritis $\left[\mathrm{F}_{0}(\mathrm{x})\right]$ pada masing-masing interval kelas.

Hipotesis:

$\mathrm{H}_{0}$ : Data mengikuti distribusi Poisson

$\mathrm{H}_{1}$ : Data tidak mengikuti distribusi Poisson

Statistik Uji

$\mathrm{D}=\max \left\{\max \left[\left|\mathrm{S}\left(x_{i}\right)-F_{0}\left(x_{i}\right)\right|,\left|\mathrm{S}\left(x_{i-1}\right)-F_{0}\left(x_{i}\right)\right|\right\}\right.$

dengan taraf signifikansi $\alpha, \mathrm{H}_{0}$ ditolak jika nilai $\mathrm{D}_{\text {hitung }}>\mathrm{D}_{\text {tabel }((1-\alpha), \mathrm{n})}$ atau $p$-value $<\alpha$. 


\subsection{Regresi Poiss on}

Model yang tepat untuk data diskrit (count) adalah model regresi Poisson yang merupakan model regresi nonlinier (Cameron dan Trivedi, 1998). Model regresi Poisson Univariat untuk variabel Y mengikuti Distribusi Poisson dengan parameter $\mu_{i}$ adalah sebagai berikut

$$
\mu_{i}=\exp \left(\boldsymbol{x}_{i}^{T} \boldsymbol{\beta}\right)
$$

dengan

$x_{i}$ adalah variabel independen yang dinotasikan dengan $\boldsymbol{x}_{\boldsymbol{i}}^{T}=\left[\begin{array}{lllll}1 & x_{1 i} & x_{2 i} & \cdots & x_{k i}\end{array}\right]$

$\beta$ adalah paremeter regresi Poisson yang dinotasikan dengan $\boldsymbol{\beta}^{\mathbf{T}}=\left[\begin{array}{lllll}\beta_{0} & \beta_{1} & \beta_{2} & \cdots & \beta_{k}\end{array}\right]$ sehingga

$\mu_{i}=\exp \left(\beta_{0}+\beta_{1} x_{1 i}+\beta_{2} x_{2 i}+\cdots+\beta_{k} x_{k i}\right)$

Penaksiran parameter untuk regresi Poisson dilakukan dengan menggunakan metode Maximum Likelihood Estimation (MLE) dengan fungsi likelihood untuk regresi Poisson univariat adalah sebagai berikut

$L(\boldsymbol{\beta})=\frac{e^{-\sum_{i=1}^{n} e^{\left(x_{i}^{T} \boldsymbol{\beta}\right)}}\left(e^{\sum_{i=1}^{n} y_{i} \boldsymbol{x}_{i}^{T} \boldsymbol{\beta}}\right)}{\prod_{i=1}^{n} y_{i} !}$

Selanjutnya dilakukan iterasi Newton Raphson untuk memaksimumkan fungsi loglikelihood dirumuskan sebagai berikut

$\ln L(\boldsymbol{\beta})=-\sum_{i=1}^{n} e^{\left(\boldsymbol{x}_{i}{ }^{T} \boldsymbol{\beta}\right)}+\sum_{i=1}^{n} y_{i} \boldsymbol{x}_{\boldsymbol{i}}{ }^{T} \boldsymbol{\beta}-\sum_{i=1}^{n} \ln \left(y_{i} !\right)$

Pengujian parameter dilakukan untuk mengetahui kesesuaian model yang terbentuk setelah diperoleh penaksir parameter pada model regresi Poisson. Pengujian parameter dilakukan secara serentak maupun parsial.

Hipotesis

$\mathrm{H}_{0}: \beta_{1}=\beta_{2}=\ldots=\beta_{k}=0$

$\mathrm{H}_{1}$ : paling sedikit ada $\beta_{j} \neq 0, j=1,2, \ldots, k$

Statistik Uji

$$
D(\widehat{\boldsymbol{\beta}})=-2 \ln \left|\frac{L(\widehat{\omega})}{L(\widehat{\Omega})}\right|
$$

Fungsi $L(\hat{\omega})$ adalah nilai maksimum likelihood untuk model tanpa melibatkan prediktor dan $L(\widehat{\Omega})$ untuk model lengkap. Kriteria pengujiannya adalah tolak $\mathrm{H}_{0}$ benar pada tingkat signifikansi a jika $D(\widehat{\boldsymbol{\beta}})>\chi_{(v, \alpha)}^{2}$ dengan $v$ adalah jumlah parameter di bawah populasi dikurangi jumlah parameter di bawah $\mathrm{H}_{0}$ benar. Jika terjadi penolakan $\mathrm{H}_{0}$ maka langkah selanjutnya adalah melakukan uji signifikansi parameter dengan hipotesis sebagai berikut.

$$
\begin{aligned}
& \mathrm{H}_{0}: \beta_{j}=0 \\
& \mathrm{H}_{1}: \beta_{j} \neq 0, \text { dengan } j=1,2, \ldots, k
\end{aligned}
$$

Statistik Uji

$$
t=\frac{\hat{\beta}_{j}}{\operatorname{se}\left(\hat{\beta}_{j}\right)}
$$

Kriteria penolakan $\mathrm{H}_{0}$ dalam pengujian ini yaitu tolak $\mathrm{H}_{0}$ jika nilai $|\mathrm{t}|>t_{\left(n-k-1, \frac{\alpha}{2}\right)}$.

\subsection{Overdispersi}

Regresi Poisson memiliki asumsi yaitu equidispersi dimana variabel dependen yang digunakan memiliki mean dan varians yang bernilai sama. Salah satu pelanggaran asumsi tersebut adalah overdispersi dimana nilai varians lebih besar dari niali mean. Overdispersi menyebabkan dugaan dari parameter koefisien regresinya tetap konsisten namun tidak efisien. Hal ini berdampak pada nilai standar error yang menjadi under estimate, sehingga kesimpulan yang diperoleh menjadi tidak valid (Cameron \& Trivedi, 1990). Menurut 
McCullagh dan Nelder (1998) untuk mendeteksi overdispersi pada regresi Poisson dapat menggunakan Pearson Chi-Square yang dibagi dengan derajat bebasnya. Formula untuk uji statistik Pearson Chi-Square adalah sebagai berikut:

$$
\chi^{2}=\sum_{i=1}^{n} \frac{\left(y_{i}-\mu_{i}\right)^{2}}{\operatorname{Var}\left(\mu_{i}\right)} \text { dengan rasio disperse } \alpha=\frac{\chi^{2}}{n-k-1}
$$

\subsection{Generalized Poisson Regression (GPR)}

Model Generalized Poisson Regression (GPR) merupakan model yang digunakan untuk data count dengan kasus over/under dispersi. Model GPR memiliki parameter $\mu$ dan satu parameter tambahan $\alpha$ (Famoye, 1997). Penaksiran parameter untuk GPR dilakukan dengan menggunakan metode Maximum Likelihood Estimation (MLE) dengan fungsi likelihood untuk GPR adalah sebagai berikut

$L(\alpha, \beta)=\prod_{i=1}^{n}\left\{\left(\frac{\mu_{i}}{1+\alpha \mu_{i}}\right)^{y_{i}} \frac{\left(1+\alpha \mu_{i}\right)^{y_{i}-1}}{y_{i} !} \exp \left(\frac{-\mu_{i}\left(1+\alpha y_{i}\right)}{1+\alpha \mu_{i}}\right)\right\}$

Selanjutnya dilakukan iterasi Newton Raphson untuk memaksimumkan fungsi loglikelihood dirumuskan sebagai berikut

$$
\ln L(\alpha, \beta)=\sum_{i=1}^{n}\left[y_{i}\left(x_{i}^{T} \beta-\ln \left(1+\alpha e^{x_{i}^{T} \beta}\right)\right)+\left(y_{i}-1\right) \ln \left(1+\alpha y_{i}\right)-\ln y_{i} !-\frac{e^{x_{i}^{T} \beta}\left(1+\alpha y_{i}\right)}{1+\alpha e^{x_{i}^{T} \beta}}\right]
$$

Pengujian parameter dilakukan untuk mengetahui kesesuaian model yang terbentuk setelah diperoleh penaksir parameter pada model GPR. Pengujian parameter dilakukan secara serentak maupun parsial.

Hipotesis

$\mathrm{H}_{0}: \beta_{1}=\beta_{2}=\ldots=\beta_{k}=0$

$\mathrm{H}_{1}$ : paling sedikit ada $\beta_{j} \neq 0, j=1,2, \ldots, k$

Statistik Uji

$$
D(\widehat{\boldsymbol{\beta}})=-2 \ln \left|\frac{L(\widehat{\omega})}{L(\widehat{\Omega})}\right|
$$

Fungsi $L(\hat{\omega})$ adalah nilai maksimum likelihood untuk model tanpa melibatkan prediktor dan $L(\widehat{\Omega})$ untuk model lengkap. Kriteria pengujiannya adalah tolak $\mathrm{H}_{0}$ benar pada tingkat signifikansi a jika $D(\widehat{\boldsymbol{\beta}})>\chi_{(v, \alpha)}^{2}$ dengan $v$ adalah jumlah parameter di bawah populasi dikurangi jumlah parameter di bawah $\mathrm{H}_{0}$ benar. Jika terjadi penolakan $\mathrm{H}_{0}$ maka langkah selanjutnya adalah melakukan uji signifikansi parameter dengan hipotesis sebagai berikut.

$$
\begin{aligned}
& \mathrm{H}_{0}: \beta_{j}=0 \\
& \mathrm{H}_{1}: \beta_{j} \neq 0, \text { dengan } j=1,2, \ldots, k
\end{aligned}
$$

Statistik Uji

$$
t=\frac{\hat{\beta}_{j}}{\operatorname{se}\left(\hat{\beta}_{j}\right)}
$$

Kriteria penolakan $\mathrm{H}_{0}$ dalam pengujian ini yaitu tolak $\mathrm{H}_{0}$ jika nilai $|\mathrm{t}|>t_{\left(n-k-1, \frac{\alpha}{2}\right)}$.

\subsection{Matriks Pembobot Spasial}

Keragaman spasial antara lokasi satu dengan lokasi lain ditunjukkan dengan adanya matriks pembobot $\mathbf{W}$ yang entri-entrinya merupakan fungsi dari jarak euclidean antar lokasi (Chasco et al., 2008). Pembentukan fungsi pembobot dari jarak euclidean salah satunya dapat menggunakan fungsi Adaptive Bisquare Kernel yang merupakan fungsi kernel dengan bandwidth yang berbeda pada setiap lokasi pengamatan. Menurut Fotheringham et al., (2002) fungsi Adaptive Bisquare Kernel dinyatakan pada persamaan 
dengan $\quad d_{i j}=\sqrt{\left(u_{i}-u_{j}\right)^{2}+\left(v_{i}-v_{j}\right)^{2}}$

$$
w_{i j}=\left\{\begin{array}{l}
\left(1-\left(\frac{d_{i j}}{h_{i}}\right)^{2}\right)^{2} ; \text { untuk } d_{i j} \leq h_{i} \\
0 \quad ; \text { untuk } d_{i j}>h_{i}
\end{array}\right.
$$

$d_{i j}$ : jarak euclidean antara lokasi $\left(u_{i}, v_{i}\right)$

$u_{i}$ : koordinat latitude (lintang) pada lokasi ke-i

$v_{i}$ : koordinat longitude (bujur) pada lokasi ke-i

$h_{i}$ : bandwidth pada lokasi ke-i

Metode yang digunakan untuk memilih bandwidth optimum adalah Cross Validation (CV) dengan rumus sebagai berikut

$$
C V(h)=\sum_{i=1}^{n}\left(y_{i}-\hat{y}_{\neq i}(h)\right)^{2}
$$

dengan $y_{i}$ adalah rata-rata dari waktu ke waktu variabel dependen di lokasi pengamatan i dan $\hat{y}_{\neq i}(h)$ adalah nilai penaksir $y_{i}$ ketika pengamatan di lokasi $\left(u_{i}, v_{i}\right)$ tidak diikutsertakan pada penaksiran dan n menunjukkan jumlah lokasi pengamatan. Bandwidth optimum dapat diperoleh ketika nilai CV minimum. Menurut Dasilva dan Mendes (2018) percobaan untuk mendapatkan nilai bandwidth yang optimum digunakan algoritma Golden Section Search (GSS).

\subsection{Geographically Weighted Generalized Poisson Regression (GWGPR)}

GWGPR merupakan metode pengembangan dari Generalized Poisson Regression namun metode ini memperhatikan pembobot berupa garis lintang dan bujur dari titik-titik pengamatan. Sehingga model GWGPR menghasilkan penaksir parameter yang bersifat lokal untuk setiap titik pengamatan. Penaksiran parameter untuk GWGPR dilakukan dengan menggunakan metode Maximum Likelihood Estimation (MLE) dengan fungsi likelihood untuk GWGPR adalah sebagai berikut

$$
L\left(\boldsymbol{\beta}\left(u_{i}, v_{i}\right)\right)=\prod_{i=1}^{n}\left(\frac{\mu_{i}}{1+\alpha \mu_{i}}\right)^{y_{i}} \frac{\left(1+\alpha \mu_{i}\right)^{y_{i}-1}}{y_{i} !} \exp \left[\frac{-\mu_{i}\left(1+\alpha y_{i}\right)}{1+\alpha \mu_{i}}\right]
$$

Selanjutnya dilakukan iterasi Newton Raphson untuk memaksimumkan fungsi loglikelihood dirumuskan sebagai berikut

$$
\begin{aligned}
\ln L\left(\boldsymbol{\beta}\left(u_{i}, v_{i}\right)\right)= & \sum_{i=1}^{n}\left[y_{i}\left(\ln e^{x_{i}^{T} \beta\left(u_{i}, v_{i}\right)}-\ln \left(1+\alpha e^{x_{i}^{T} \beta\left(u_{i}, v_{i}\right)}\right)\right)+\left(y_{i}-1\right) \ln \left(1+\alpha y_{i}\right)\right. \\
& \left.-\ln y_{i} !-\frac{e^{x_{i}^{T} \beta\left(u_{i}, v_{i}\right)}\left(1+\alpha y_{i}\right)}{1+\alpha e^{x_{i}^{T} \beta\left(u_{i}, v_{i}\right)}}\right]
\end{aligned}
$$

Pengujian parameter dilakukan untuk mengetahui kesesuaian model yang terbentuk setelah diperoleh penaksir parameter pada model GWGPR. Pengujian parameter dilakukan secara serentak maupun parsial.

Hipotesis

$\mathrm{H}_{0}: \beta_{1}\left(u_{i}, v_{i}\right)=\beta_{2}\left(u_{i}, v_{i}\right)=\ldots=\beta_{k}\left(u_{i}, v_{i}\right)=0$

$\mathrm{H}_{1}$ : paling sedikit ada $\beta_{j}\left(u_{i}, v_{i}\right) \neq 0, j=1,2, \ldots, k$

Statistik Uji

$$
D(\widehat{\boldsymbol{\beta}})=-2 \ln \left|\frac{L(\widehat{\omega})}{L(\widehat{\Omega})}\right|
$$

Fungsi $L(\hat{\omega})$ adalah nilai maksimum likelihood untuk model tanpa melibatkan prediktor dan $L(\widehat{\Omega})$ untuk model lengkap. Kriteria pengujiannya adalah tolak $\mathrm{H}_{0}$ benar pada tingkat signifikansi $\alpha$ jika $D(\widehat{\boldsymbol{\beta}})>\chi_{(v, \alpha)}^{2}$ dengan $v$ adalah jumlah parameter di bawah populasi 
dikurangi jumlah parameter di bawah $\mathrm{H}_{0}$ benar. Jika terjadi penolakan $\mathrm{H}_{0}$ maka langkah selanjutnya adalah melakukan uji signifikansi parameter dengan hipotesis sebagai berikut.

$\mathrm{H}_{0}: \beta_{j}\left(u_{i}, v_{i}\right)=0$

$\mathrm{H}_{1}: \beta_{j}\left(u_{i}, v_{i}\right) \neq 0$, dengan $j=1,2, \ldots, k$

Statistik Uji

$Z=\frac{\hat{\beta}_{j}\left(u_{i}, v_{i}\right)}{\operatorname{Se}\left(\hat{\beta}_{j}\left(u_{i}, v_{i}\right)\right)}$

Kriteria penolakan $\mathrm{H}_{0}$ dalam pengujian ini yaitu tolak $\mathrm{H}_{0}$ jika nilai $|\mathrm{Z}|>Z_{\alpha / 2}$

\subsection{Akaike Information Criterion}

Akaike Information Criterion (AIC) merupakan salah satu kriteria untuk menentukan model terbaik. Semakin kecil nilai AIC, maka model semakin baik dan layak untuk digunakan. Nilai AIC dirumuskan pada persamaan berikut ini (Bozdogan, 2000)

$$
A I C=-2 \ln L(\hat{\beta})+2 k
$$

$\mathrm{k}=$ banyaknya parameter yang digunakan

$L(\hat{\beta})=$ nilai maksimal likelihood

\section{METODOLOGI PENELITIAN}

\subsection{Jenis dan Sumber Data}

Data yang digunakan dalam penelitian ini berupa data sekunder yang bersumber dari Laporan Profil Kesehatan Provinsi Jawa Tengah tahun 2017. Unit penelitian yang digunakan adalah Kabupaten/Kota di Jawa Tengah yang terdiri dari 35 Kabupaten/Kota.

\subsection{Variabel Penelitian}

Variabel dependen dalam penelitian ini adalah jumlah kematian ibu nifas (Y) di Jawa Tengah pada tahun 2017. Variabel independen terdiri dari 3 variabel yaitu persentase komplikasi kebidanan yang ditangani $\left(\mathrm{X}_{1}\right)$, persentase rumah tangga berperilaku hidup bersih dan sehat $\left(\mathrm{X}_{2}\right)$, dan persentase ibu hamil melakukan $\mathrm{K} 1\left(\mathrm{X}_{3}\right)$.

\subsection{Langkah-langkah Penelitian}

1. Membuat deskripsi data jumlah kematian ibu nifas serta faktor-faktor yang mempengaruhinya pada setiap kabupaten/kota di Jawa Tengah tahun 2017 menggunakan statistika deskriptif.

2. Melakukan Uji Kecocokan Distribusi Poisson.

3. Melakukan Deteksi Multikolinearitas menggunakan kriteria VIF untuk mengetahui apakah antar variabel independen memiliki hubungan yang erat.

4. Melakukan pemodelan dengan regresi Poisson yang meliputi :

a. Mengestimasi parameter model regresi Poisson dengan memaksimumkan fungsi log-likelihood.

b. Melakukan pengujian signifikansi parameter secara serentak menggunakan Likelihood Ratio Test dan secara parsial menggunakan nilai t.

5. Menguji asumsi overdispersi model regresi Poisson

6. Melakukan pemodelan dengan GPR yang meliputi :

a. Mengestimasi parameter model GPR dengan memaksimumkan fungsi loglikelihood.

b. Melakukan pengujian signifikansi parameter secara serentak menggunakan Likelihood Ratio Test dan secara parsial menggunakan nilai t.

7. Melakukan pemodelan dengan GWGPR yang meliputi :

a. Menentukan jarak euclidean antar lokasi pengamatan berdasarkan posisi geografis. Jarak euclidean antara lokasi i yang terletak pada koordinat $\left(\mathrm{u}_{\mathrm{i}}, \mathrm{v}_{\mathrm{i}}\right)$ terhadap lokasi $\mathrm{j}$ yang terletak pada koordinat $\left(\mathrm{u}_{\mathrm{i}}, \mathrm{v}_{\mathrm{i}}\right)$ 
b. Menentukan bandwidth yang optimum berdasarkan nilai CV yang minimum

c. Menentukan pembobot dengan menggunakan fungsi kernel yang terpilih

d. Mengestimasi parameter model GWGPR dengan memaksimumkan fungsi lnlikelihood dengan persamaan

e. Melakukan pengujian signifikansi parameter secara serentak menggunakan Likelihood Ratio Test dan secara parsial menggunakan nilai $\mathrm{Z}$

8. Mengelompokkan Kabupaten/Kota berdasarkan variabel signifikan yang sama pada model GWGPR.

9. Membandingkan nilai AIC dari model regresi Poisson, GPR dan GWGPR

10. Menentukan model terbaik berdasarkan nilai AIC terkecil.

\section{HASIL DAN PEMBAHASAN}

\subsection{Statis tika Deskriptif}

Tabel 1. Statistika Deskriptif

\begin{tabular}{ccccc}
\hline Variabel & Rata-rata & Varian & Min & Max \\
\hline $\mathrm{Y}$ & 8,00 & 18,77 & 0,00 & 19,00 \\
$\mathrm{X}_{1}$ & 114,77 & 485,02 & 75,10 & 171,50 \\
$\mathrm{X}_{2}$ & 79,22 & 95,59 & 59,69 & 97,25 \\
$\mathrm{X}_{3}$ & 99,08 & 7,89 & 85,21 & 100,00 \\
\hline
\end{tabular}

\subsection{Uji Kecocokan Dis tribusi}

Pengujian kecocokan Distribusi Poisson untuk data jumlah kematian ibu nifas dengan hipotesis berikut

$\mathrm{H}_{0}$ : Data jumlah kematian ibu nifas mengikuti distribusi Poisson

$\mathrm{H}_{1}$ : Data jumlah kematian ibu nifas tidak mengikuti distribusi Poisson

dengan taraf signifikansi $\alpha=0,05$ diperoleh nilai $\mathrm{D}_{\text {hitung }}=0,16436<\mathrm{D}_{\text {tabel }}=0,224$ dan $p$ value sebesar 0,3008 > $\alpha=0,05$ sehingga $\mathrm{H}_{0}$ diterima, maka data jumlah kematian ibu nifas mengikuti Distribusi Poisson.

\subsection{Deteksi Multikolinieritas}

Setelah melakukan Uji Distribusi langkah selanjutnya adalah melakukan pemeriksaan multikolinieritas untuk mengetahui apakah antara variabel independen memiliki hubungan yang erat.

Tabel 2. VIF Kasus Kematian Ibu Nifas

\begin{tabular}{cc}
\hline Variabel & VIF \\
\hline $\mathrm{X}_{1}$ & 1,05078 \\
$\mathrm{X}_{2}$ & 1,08320 \\
$\mathrm{X}_{3}$ & 1,07729
\end{tabular}

Pada kasus kematian ibu nifas nilai VIF pada semua variabel independen kurang dari 10. Hal ini mengindikasikan bahwa tidak terjadi multikolinieritas pada variabel independen.

\subsection{Regresi Poisson}

Dalam menentukan model regresi yang tepat pada Regresi Poisson terlebih dahulu dilakukan pengujian parameter secara serentak dan secara parsial. Berdasarkan nilai $D(\widehat{\boldsymbol{\beta}})=$ 204,2 lebih besar dari $\chi_{(3 ; 0,05)}^{2}=7,815$ maka $\mathrm{H}_{0}$ ditolak secara serentak variabel independen berpengaruh terhadap jumlah kematian ibu nifas di Jawa Tengah tahun 2017. Langkah selanjutnya adalah melakukan pengujian parameter secara parsial. Hipotesis pada pengujian parameter secara parsial 
Tabel 3. Estimasi Parameter Kasus Kematian Ibu Nifas

\begin{tabular}{cccccc}
\hline Parameter & Estimasi & Standar Error & t-hitung & p-value & Keputusan \\
\hline$\beta_{0}$ & 7,5625 & 2,1610 & 3,48 & 0,0014 & $\mathrm{H}_{0}$ ditolak \\
$\beta_{1}$ & $-0,0339$ & 0,0194 & $-1,74$ & 0,0899 & $\mathrm{H}_{0}$ diterima \\
$\beta_{2}$ & $-0,0057$ & 0,0029 & $-1,96$ & 0,0576 & $\mathrm{H}_{0}$ diterima \\
$\beta_{3}$ & 0,0181 & 0,0064 & $-2,84$ & 0,0075 & $\mathrm{H}_{0}$ ditolak \\
\hline
\end{tabular}

Berdasarkan tabel $3 \mathrm{H}_{0}$ ditolak untuk variabel persentase ibu hamil melaksanakan Kunjungan Pertama $\left(\mathrm{X}_{3}\right)$, artinya variabel tersebut berpengaruh signifikan terhadap jumlah kematian ibu nifas di Jawa Tengah tahun 2017. Pada Regresi Poisson kematian ibu nifas di Jawa Tengah tahun 2017 diperoleh nilai AIC sebesar 212.20. Maka model akhirnya adalah sebagai berikut

\subsection{Overdis persi}

$$
\hat{\mu}=\exp \left(7,5265-0,0339 X_{1}-0,0057 X_{2}-0,0181 X_{3}\right)
$$

Analisis adanya kasus overdispersi digunakan untuk mengetahui apakah model regresi Poisson yang diperoleh memenuhi asumsi.

Tabel 4. Nilai Pearson Chi-Squre untuk Model Regresi Poisson

\begin{tabular}{cccc}
\hline Kriteria & Nilai & DF & Nilai/DF \\
\hline Pearson Chi-Squre & 72,9806 & 31 & 2,3542 \\
\hline
\end{tabular}

Tabel 4 menunjukkan nilai Pearson Chi-Squre dari model regresi Poisson adalah 72.9806. Jika nilai tersebut dibagi dengan derajat bebasnya maka akan menghasilkan nilai dispersi sebesar 2,3542 yang nilai tersebut lebih besar dari 0 yang menunjukan terjadinya overdispersi. Dari hal tersebut maka dapat disimpulkan bahwa data jumlah kematian ibu nifas di Provinsi Jawa Tengah tahun 2017 mengalami overdispersi. Untuk mengatasi hal tersebut maka digunakan model GPR dalam pemodelan data.

\subsection{Generalized Poisson Regression (GPR)}

Dalam menentukan model regresi yang tepat pada GPR terlebih dahulu dilakukan pengujian parameter secara serentak dan secara parsial. Berdasarkan nilai $D(\widehat{\boldsymbol{\beta}})=194,1$ lebih besar dari $\chi_{(3 ; 0,05)}^{2}=7,815$ maka $\mathrm{H}_{0}$ ditolak secara serentak variabel independen berpengaruh terhadap jumlah kematian ibu nifas di Jawa Tengah tahun 2017. Langkah selanjutnya adalah melakukan pengujian parameter secara parsial. Hipotesis pada pengujian parameter secara parsial

Tabel 5. Estimasi Parameter Kasus Kematian Ibu Nifas

\begin{tabular}{cccccc}
\hline Parameter & Estimasi & Standar Error & t-hitung & $\mathrm{p}$-value & Keputusan \\
\hline$\beta_{0}$ & 7,8781 & 3,3230 & 2,37 & 0,0233 & $\mathrm{H}_{0}$ ditolak \\
$\beta_{1}$ & $-0,0349$ & 0,0300 & $-1,16$ & 0,2529 & $\mathrm{H}_{0}$ diterima \\
$\beta_{2}$ & $-0,0066$ & 0,0043 & $-1,54$ & 0,1345 & $\mathrm{H}_{0}$ diterima \\
$\beta_{3}$ & 0,0120 & 0,0096 & $-2,09$ & 0,0441 & $\mathrm{H}_{0}$ ditolak \\
\hline
\end{tabular}

Berdasarkan tabel $5 \mathrm{H}_{0}$ ditolak untuk variabel persentase ibu hamil melaksanakan Kunjungan Pertama $\left(\mathrm{X}_{3}\right)$, artinya variabel tersebut berpengaruh signifikan terhadap jumlah kematian ibu nifas di Jawa Tengah tahun 2017. Pada GPR kematian ibu nifas di Jawa Tengah tahun 2017 diperoleh nilai AIC sebesar 204,10. Maka model akhirnya adalah sebagai berikut

$$
\hat{\mu}=\exp \left(7,8781-0,0349 X_{1}-0,0066 X_{2}-0,0120 X_{3}\right)
$$

\subsection{Geographically Weighted Generalized Poisson Regression (GWGPR)}

Dalam menentukan model yang tepat pada GWGPR terlebih dahulu dilakukan pengujian parameter secara serentak dan secara parsial. Berdasarkan nilai $D(\widehat{\boldsymbol{\beta}})=103,6304$ lebih besar dari $\chi_{(3 ; 0,05)}^{2}=7,815$ maka $\mathrm{H}_{0}$ ditolak secara serentak variabel independen 
berpengaruh terhadap jumlah kematian ibu nifas di Jawa Tengah tahun 2017. Langkah selanjutnya adalah melakukan pengujian parameter secara parsial. Hipotesis pada pengujian parameter secara parsial.

Tabel 6. Estimasi Parameter Kasus Kematian Ibu Nifas

\begin{tabular}{cccc}
\hline Parameter & Estimasi & Z hitung & Keputusan \\
\hline$\beta_{0}$ & 5,80730 & 0,001 & $\mathrm{H}_{0}$ diterima \\
$\beta_{1}$ & $-0,01385$ & $-2046,030$ & $\mathrm{H}_{0}$ ditolak \\
$\beta_{2}$ & $-0,00286$ & 225,777 & $\mathrm{H}_{0}$ ditolak \\
$\beta_{3}$ & $-0,01260$ & 6,097 & $\mathrm{H}_{0}$ ditolak \\
\hline
\end{tabular}

Berdasarkan tabel $6 \mathrm{H}_{0}$ ditolak untuk variabel persentase komplikasi kebidanan yang ditangani $\left(\mathrm{X}_{1}\right)$, persentase rumah tangga berperilaku hidup bersih dan sehat $\left(\mathrm{X}_{2}\right)$, dan persentase ibu hamil melaksanakan Kunjungan Pertama $\left(\mathrm{X}_{3}\right)$, artinya variabel tersebut berpengaruh signifikan terhadap jumlah kematian ibu nifas di Kabupaten Kendal tahun 2017. Pada GWGPR kematian ibu nifas di Jawa Tengah tahun 2017 diperoleh nilai AIC sebesar 113,63. Maka model akhirnya adalah sebagai berikut

$$
\hat{\mu}_{24}=\exp \left(5,80730-0,01385 X_{1}-0,00286 X_{2}-0,01260 X_{3}\right)
$$

Berikut merupakan peta yang menggambarkan pengelompokan Kabupaten/Kota berdasarkan variabel yang signifikan pada Gambar 1

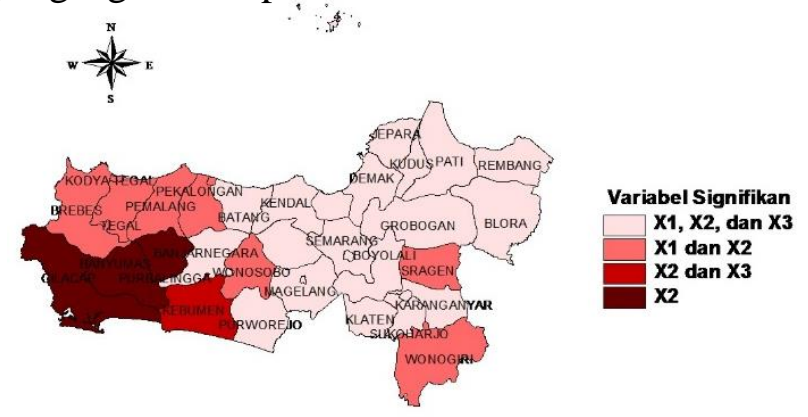

Gambar 1. Pengelompokan Kabupaten/Kota Berdasarkan Variabel Signifikan

\subsection{Penentuan Model Terbaik dengan AIC}

Akaike Information Criterion (AIC) merupakan salah satu kriteria untuk menentukan model terbaik. Semakin kecil nilai AIC, maka model semakin baik dan layak untuk digunakan. Berdasarkan pemodelan yang telah dilakukan diperoleh nilai AIC pada setiap model sebagai berikut.

Tabel 7. Nilai AIC

\begin{tabular}{|c|c|}
\hline Metode & AIC \\
\hline Regresi Pois son & 212,20 \\
\hline Generalized Poisson Regression (GPR) & 204,10 \\
\hline $\begin{array}{c}\text { Geographically Weighted Generalized Poisson } \\
\text { Regression (GWGPR) }\end{array}$ & 113,63 \\
\hline
\end{tabular}

Berdasarkan Tabel 7 nilai AIC pada model GWGPR merupakan model terbaik karena memiliki nilai AIC terkecil yaitu sebesar 113.63

\section{KESIMPULAN}

Berdasarkan analisis dan pembahasan dapat diambil kesimpulan sebagai berikut:

1. Pada Regresi Poisson dan GPR kasus kematian ibu nifas terdapat satu variabel independen yang berpengaruh signifikan yaitu variabel persentase ibu hamil melaksanakan Kunjungan Pertama $\left(\mathrm{X}_{3}\right)$. 
2. Model GWGPR yang dihasilkan untuk setiap lokasi akan berbeda antara satu dengan yang lainnya. Berikut salah satu Model GWGPR yang terbentuk dengan pembobot Adaptive Bisquare Kernel untuk lokasi pengamatan ke 24 yaitu Kabupaten Kendal:

$$
\hat{\mu}_{24}=\exp \left(5,80730-0,01385 X_{1}-0,00286 X_{2}-0,01260 X_{3}\right)
$$

3. Variabel yang signifikan mempengaruhi kematian ibu nifas untuk lokasi pengamatan di Kabupaten Kendal adalah persentase komplikasi kebidanan yang ditangani, persentase rumah tangga berperilaku hidup bersih dan sehat, dan persentase ibu hamil melakukan kunjungan pertama (K1).

\section{DAFTAR PUSTAKA}

Bahiyatun. 2008. Buku Ajar Asuhan Kebidanan Nifas Normal. Jakarta: Penerbit Buku Kedokteran EGC.

[Bappenas] Badan Perencanaan Pembangunan Nasional. 2014. Rencana Pembangunan Jangka Menengah Nasional 2015-2019: Buku I Agenda Pembangunan Nasional. Jakarta: Badan Perencanaan Pembangunan Nasional.

Bozdogan, H. 2000. Akaike's Information Criterion and Recent Developments in Information Complexity. Mathematical Psychology.

Cameron, A.C. dan Trivedi, K.P. 1998. Regression Analysis of Count Data. USA:Cambridge University Press.

Da Silva, A. R., da Mendes, F. F. 2018. On Comparing Some Algorithms for Fiding the Optimal Bandwidth in Geographically Weighted Regression. Applied Soft Computing Journal. 73. 943-957

[Dinkes Jateng] Dinas Kesehatan Provinsi Jawa Tengah. 2018. Profil Kesehatan Provinsi Jawa Tengah Tahun 2017. Semarang: Dinas Kesehatan Provinsi Jawa Tengah.

Fotheringham, A.S., Brudson, C., dan Charlton, M. 2002. Geographically Weighted Regression. Analysis os Spatial Varying Relationship. John Wiley and Sons Ltd: England

[Kemenkes RI] Kementerian Kesehatan Republik Indonesia. 2017. Profil Kesehatan Indonesia Tahun 2016. Jakarta: Republik Indonesia.

McCullagh, P. dan J.A. Nelder. 1989. Generalized Linear Models. Second Edition. New York: Chapman and Hall.

Myers, M. V. 1990. Generalized Linear Model with Applications in Engineering and Sciences, 2th Edition. New Jersey: John Wiley \& Sons.

Wang, W. dan Famoye, F. 1997. Modeling household fertility decision with generalized Poisson regression. Journal of Population Economics, 10, 3, 273283. 